Jurnal Inovatif Ilmu Pendidikan Vol.1 No.2, (2019) Hlm. 101-112

http://jurnal.fkip.unila.ac.id/index.php/JIIP/index

Email : inovatif.ip@fkip.unila.ac.id

\title{
Mengembangkan Keterampilan Motorik Halus Anak Melalui Kegiatan 3 M
}

\author{
Sri Ayu Laali \\ Pendidikan Anak Usia Dini, Universitas Muhammadiyah Luwuk \\ Jl. KH. Ahmad Dahlan No. III/79 Luwuk Kab. Banggai Sulawesi TengahTelp./Fax. \\ 0461-21725 \\ E-mail: ayulaaly1989@gmail.com
}

\begin{abstract}
Article Info
Received Juni 2019

Accepted September 2019

Published Oktober 2019

Keywords:

Fine motor skills, early childhood, activities (coloring, cutting and sticking)

Abstract

The purpose of this study was to describe the development of fine motor skills through $3 M$ activities (coloring, cutting and sticking) on students in the B2 kindergarten group Al-Ittihad. This study is a Classroom Action Research $(C A R)$. The procedure for implementing classroom action research consists of two cycles. Each cycle is carried out in accordance with the changes to be achieved as what has been designed in the factors to be investigated. The subjects in this study were as many as 20 people consisting of 10 male children and 10 female students in Musdalifah Poasia Kindergarten 2010/2011 Academic Year. From the results of the evaluation of observations, it can be concluded that through $3 M$ activities (coloring, cutting and sticking) that are carried out optimally can develop the fine motoric abilities of students in the kindergarten Al-Ittihad B2 group. Recommendations for further research in order to re-raise the same problems but with other methods, techniques and strategies as well as different actions in order to provide input or new findings in optimally developing the potential of students in kindergarten
\end{abstract}

\begin{abstract}
Abstrak: Tujuan dalam penelitian ini adalah untuk mendeskripsikan pengembangan keterampilan motorik halus melalui kegiatan $3 \mathrm{M}$ (mewarnai, menggunting dan menempel) pada anak didik kelompok B2 TK Al-Ittihad Luwuk. Penelitian ini merupakan Penelitian Tindakan Kelas (PTK). Prosedur pelaksanaan penelitian tindakan kelas ini terdiri dari dua siklus. Tiap siklus dilaksanakan sesuai dengan perubahan yang ingin dicapai seperti apa yang telah didesain dalam faktor-faktor yang ingin diselidiki. Subyek dalam penelitian ini adalah sebanyak 20 orang yang terdiri dari anak laki-laki 10 orang dan anak perempuan 10 orang anak didik TK Al-Ittihad Luwuk Tahun Pelajaran 2018/2019. Dari hasil evaluasi observasi, maka dapat disimpulkan bahwa melalui kegiatan 3M (mewarnai, menggunting dan menempel) yang dilaksanakan secara optimal dapat mengembangkan kemampuan motorik halus anak didik kelompok B2 TK Al-Ittihad. Rekomendasi bagi penelitian selanjutnya agar dapat mengangkat kembali permasalahan yang sama tetapi dengan metode, teknik dan strategi yang lain serta tindakan yang berbeda agar dapat memberi masukan atau temuan-temuan baru dalam mengembangkan potensi anak didik di Taman Kanak-Kanak secara optimal.
\end{abstract}

Kata Kunci : Motorik Halus, Anak, Aktifitas (mewarnai, menggunting, menempel) 


\section{PENDAHULUAN}

Anak adalah individu unik yang memiliki kekhasan tersendiri. Kajian tentang anak selalu menarik sehingga memunculkan berbagai pandangan tentang hakikat seorang anak sebenarnya. Ada yang berpandangan bahwa anak adalah miniatur atau bentuk kecil orang dewasa, ada pula orang yang beranggapan bahwa anak ibarat kertas kosong yang bisa ditulis apapun.

Anak tidak memiliki potensi, ia hanya menjadi apa yang diinginkan oleh lingkungannya. Bahkan ada yang memandang bahwa anak memiliki dosa yang diturunkan oleh orang tuanya. Meski demikian, tidak sedikit pula yang beranggapan bahwa anak pada dasarnya dilahirkan dengan membawa potensi yang akan berkembang dan menjadi penentu dalam kehidupannya dimasa yang akan datang.

Anak berbeda satu sama lain. Anak memiliki bawaan, minat, kapabilitas/kemampuan dan latar belakang kehidupan masing-masing. Hal itulah yang menunjukkan bahwa anak bersifat unik. Meskipun demikian terdapat pola urutan umum perkembangan anak yang dapat diprediksi/diperkirakan, namun pola perkembangan dan belajarnya tetapi memiliki perbedaan satu sama lain.

Program pengembangan keterampilan motorik anak usia dini seringkali terabaikan atau dilupakan oleh orang tua, pembimbing atau bahkan guru sendiri.Hal ini disebabkan mereka belum memahami bahwa program pengembangan keterampilan motorik menjadi bagian yang tidak terpisahkan dalam kehidupan anak usia dini. Bertitik tolak dari hal tersebut dirasakan perlu adanya pengembangan suatu model program pengembangan keterampilan motorik anak usia dini, agar semua pihak yang berkepentingan khususnya para pendidik dapat memahami dan mampu menerapkan pada anak didiknya.

Kegiatan mewarnai, menggunting dan menempel ( $3 \mathrm{M}$ ) merupakan kegiatan yang mempunyai kaitan dengan kemampuan-kemampuan menggunakan alat serta melatih motorik halus anak. Motorik halus ini akan menjadi dasar kemampuan yang sensitif anak terhadapgejala-gejala yang melingkupi kehidupan anak baik masa anak maupun setelah dewasa yang berkaitan dengan ketelitian berkarya. Mereka akan cepat tanggap terhadap apa yang terjadi pada lingkungan sekelilingnya, sehingga 
mereka akan terampil menyesuaikan diri dalam merespon gelajalanya. Kemampuan tersebut harus dikembangkan agar kelak dapat menunjang kegiatan skolastik mereka. Dari sikap sensitif dan tanggap maka anak akan mudh mengakses gejala disekelilingnya yang pada akhirnya dapat mengimplementasikan disiplin keilmuan lain.

Kegiatan 3M tersebut merupakan rangkaian kegiatan yang berkesinambungan menghasilkan karya yang sempurna dari hasil kerja anak, mulai dari kemampuan anak untuk mewarnai gambar, selanjutnya menggunting gambar yang telah diwarnai tersebut setelah itu dilanjutkan dengan kegiatan menempel hasil karya tersebut pada tempat yang telah tersedia. Melalui kegiatan ini pula anak dilatih sedini mungkin memiliki tanggung jawab terhadap pekerjaan atau tugas yang diberikan mulai dari awal hingga akhir.

Berdasarkan hal tersebut diatas, dari hasil pengamatan peneliti pada TK AlIttihad, terlihat bahwa kegiatan 3M tersebut sebenarnya sudah dilakukan tetapi hanya terbatas pada satu tahap jenis kegiatan saja, misalnya hanya mewarnai gambar, menggunting dan selanjutnya menempel hasil karya. Hal inilah yang menjadi perhatian peneliti, jika kegiatan tersebut diperbaharui satu tahapan kegiatan dimana kegiatan kegiatan diatas dirangkum menjadi satu tahap yaitu 3M (mewarnai, menggunting dan menempel).

Diharapkan pula melalui kegiatan ini anak-anak dapat menyelesaikan kegiatan sampai selesai dan menjadi modal bagi anak untuk sedini mungkin memiliki tanggung jawab terhadap apa yang ia kerjakan selain itu yang terpenting adalah kegiatan ini melatih motorik halus anak yang akan menjadi belak anak dimasa mendatang.

\section{Kemampuan Motorik Halus Anak}

Menurut Soemantri (2005), Motorik halus merupakan keterampilan motorik yang berbeda memainkan peranan yang berbeda pula dalam penyesuaian sosial dan pribadi anak. Sebagai contoh keterampilan berfungsi membantu anak untuk memperoleh kemandiriannya, sedangkan sebagian lainnya berfungsi untuk mendapatkan penerimaan sosial.

Hal yang sama dikemukakan oleh Mahendra (1998), keterampilan motorik halus (fine motor skill) merupakan keterampilan-keterampilan yang memerlukan 
kemampuan untuk mengontrol otot-otot kecil / halus untuk mencapai pelaksanaan keterampilan yang berhasil. Keterampilan ini melibatkan koordinasi neuromusculer (syaraf otak) yang memerlukan ketepatan derajat tinggi untuk berhasilnya keterampilan ini. Keterampilan jenis ini sering disebut keterampilan yang memerlukan koordinasi mata-tangan (hand-eye coordination), menulis, menggambar, bermain, piano adalah contoh-contoh keterampilan tersebut.

Menurut Iskandar (2009), bahwa dalam keterampilan motorik halus yang dipergunakan adalah sekelompok otot-otot kecil, seperti jari-jari tangan, lengan dan sering membutuhkan kecermatan dan koordinasi mata dan tangan. Keterampilan ini mencakup pemanfaatan alat-alat untuk bekerja. Obyek yang kecil atau mengontrolan mesin. Tugas-tugas seperti menari, memainkan musik, mengetik, menjahit, menulis, mengemudikan pesawat dan lain-lain.

Perkembangan fisik motorik anak menurut Masitoh (2004), bahwa ketika anak mencapai tahapan usia TK (3 sampai 6 tahun), terdapat ciri yang sangat berbeda dengan usia bayi. Perbedaannya terletak pada penampilan, proporsi tubuh, berat dan panjang badan, serta keterampilan yang dimiliki. Kalau anda perhatikan, pada anak usia TK telah nampak otot-otot tubuh yang berkembang sehingga memungkinkan mereka melakukan berbagai jenis keterampilan.

Dari paparan beberapa para ahli di atas dapat disimpulkan bahwa kemampuan motorik halus adalah sekelompok otot-otot kecil yang berkembang sehingga memungkinkan mereka melakukan berbagai jenis keterampilan yang berkaitan dengan koordinasi antara otot kecil dan otak.

\section{Kegiatan 3M (Menempel, menggunting dan menempel)}

Kegiatan $3 \mathrm{M}$ merupakan yang berkaitan dengan kemampuan menggunakan alat indera serta melatih motorik halus anak. Motorik halus anak ini akan menjadi dasar kemampuan yang sensitif anak terhadap gejala-gejala yang melingkupi kehidupan anak baik masa anak maupun setelah dewasa yang berkaitan dengan ketelitian berkarya. Mereka akan mudah dan cepat tanggap terhadap apa yang terjadi pada lingkungan sekelilingnya, sehingga mereka akan terampil menyesuaikan diri dalam merespons gejalanya. Kemampuan tersebut harus dikembangkan agar kelak dapat menunjang kegiatan skolastik mereka. 
Kegiatan mewarnai gambar merupakan kegiatan untuk mendapatkan kemampuan-kemampuan yang berguna bagi perkembangan pendidikan anak, meliputi:1) Memilih warna, adalah melatih menanamkan sikap anak untuk memilih warna yang mereka anggap bagus dan ia suka sebagai awal penanaman sikap anak terhadap apa yang ia hadapi. 2) Menyusun warna, dpat melatih nilai-nilai perbandingan yang bersifat rasa antara satu dengan lainnya, melatih bagaimana memilih dan menempatkan bagian satu dengan yang lainnya. 3) Menuangkan warna, adalah tindakan fisik dimana anak melakukan gerkan mengoles dan mengendalikan gerak tangan.

Dari kegiatan ini anak akan terampil mewarnai dengan benar, tidak keluar dari objek gambar yang diwarnai, dan mewarnai dengan rapi. Kegiatan ini juga dapat melatih perasaan halus, sabar dan teliti pada anak. Selanjutnya kegiatan menggunting, dimana kegiatan ini dapat dilakukan dengan cara menggunting diluar objek gambar yang diwarnai dengan jarak kira-kira $1 \mathrm{~mm}$ sehingga ruang warna tidak dikurangi dan tidak ada kelebihan kertas putih.

Objek gambar yang diwarnai dengan media kering akan tidak banyak memiliki kesulitan pada waktu pengguntingan karena kertas tetap dalam keadaan kering sehingga langsung dapat dipotong dengan menggunakan gunting sedangkan objek gambar yang diwarnai dengan media basah akan lebih sulit pemotongannya.

Menempel, kegiatan ini merupakan kelanjutan dari kegiatan menggunting. Kegiatan ini merupakan finishing, dari kegiatan $3 \mathrm{M}$, karena apabila proses penempelan dilakukan berakhirlah kegiatan $3 \mathrm{M}$. Anak pasti memahami bahwa anak usia dini masih sangat tergantung orang lain dalam mengerjakan kegiatan seni. Maka anak sebagai pendidiknya sebaiknya membimbing dengan cara membantu sambil ikut memegangi kertas gambar yang akan ditempelkan karena proses menempel ini sangat diperlukan latihan secara berulang-ulang, untuk meletakkan kertas yang sudah diolesi lem akan sangat sulit bagi anak, sebab kertas yang sudah diolesi lem begitu menempel kertas lain. 


\section{METODE}

Penelitian ini tergolong ke dalam Penelitian Tindakan Kelas (PTK). Dikatakan Penelitian Tindakan Kelas karena peneliti secara langsung menerapkan suatu perlakuan atau tindakan untuk menangani suatu masalah, dalam hal ini mengembangkan kemampuan motorik halus melalui kegiatan 3M (Mewarnai, menggunting dan menempel) pada anak didik kelompok B2 TK Al-Ittihad, sedangkan lokasi penelitian yaitu di TK Al-Ittihad Luwuk dilaksanakan pada semester II Tahun Pelajaran 2018/2019 sedangkan subjek penelitian dengan jumlah anak didik sebanyak 20 orang yang terdiri dari anak laki-laki 10 orang dan anak perempuan 10 orang.

Teknik pengumpulan data berupa observasi dan wawancara yang bersifat reflektif, partisipatif dan kolaboratif, dimana hal ini dilakukan dalam beberapa siklus tindakan sesuai kebutuhan dilapangan, yang didahului dengan tindakan supervision yakni ; melakukan perencanaan dan survei awal, observasi dan evaluasi awal/testing awal. Selajutnya, setelah permasalahan mendasar dalam kegiatan survei awal tersebut diketahui maka dilanjutkan dengan tindakan perbaikan dimana hal ini dilakukan berkolaborasi dengan guru sebagai rekan sejawat sesuai dengan perencanaan dan kesepakatan bersama.

Tahapan atau prosedur kegiatan pada setiap siklus dalam melaksanakan penelitian, yaitu : 1) Perencanaan (Planning),; merencanakan kegiatan atau tindakan yang dilakukan, 2) Aksi dan tindakan (acting).; melaksanakan kegiatan penelitian sesuai dengan perencanaan yang telah disusun, 3) Observasi (observing) melaksanakan kegiatan observasi (pengamatan) dan melaksanakan kegiatan penilaian / evaluasi untuk melihat kemampuan anak. 4) Refleksi; melakukan kegiatan merefleksi segala kegiatan yang dilakukan dalam rangka perbaikan.

Tehnik analisis data dilaksanakan dengan menggunakan analisis deskriftif, baik deskriptif kualitatif maupun deskriftif kuantitatif. Metode deskriptif adalah metode analisis yang menggambarkan fenomena penelitian secara objektif. Deskriptif kualitatif yang menggambarkan fenomena secara kualitatif (tanpa menyebut angka), sedangkan deskriptif kuantitatif yaitu metode analisis yang menggambarkan fenomena menggunakan angka, angka tersebut tertuang dalam bentuk presentase ketuntasan belajar anak secara klasikal. 
Dalam menganalisis data dan memberi penilaian pada setiap indikator aspek pengamatan, peneliti menggunakan kriteria bentuk penilaian yang selama ini di gunakan guru TK untuk menilai kemampuan awal dan aktivitas anak dalam kegiatan pembelajaran melalui kegiatan $3 \mathrm{M}$ dengan di TK Al-Ittihad, yaitu penilaian secara kualitatif atau dengan memberikan nilai dalam bentuk simbol-simbol seperti: $\mathrm{O}=$ Baik, yaitu jika anak memiliki kemampuan motorik halus anak tanpa dibimbing oleh guru); $\sqrt{ }=$ Cukup, jika anak telah memiliki kemampuan motorik halus tetapi masih perlu dibimbing guru namun tidak secara langsung); $\mathrm{O}=$ Kurang, jika anak memiliki kemampuan motorik halus dengan bimbingan secara langsung oleh atau masih dibimbing dari awal hingga akhir, (Depdiknas, 2003).

\section{HASIL DAN PEMBAHASAN}

Dari hasil pertemuan dengan guru kelompok maka peneliti memberikan beberapa keterangan / informasi tentang tahap-tahap pelaksanaan kegiatan dan hasil yang diinginkan dari setiap pelaksanaan kegiatan tersebut. Selanjutnya peneliti bersama guru kelompok B2 Al-Ittihad Luwuk telah sepakat untuk berkoordinasi dan menjadi mitra peneliti dalam kegiatan penelitian, Setelah itu bersama-sama merancang Rencana Kegiatan Harian (RKH) yang akan digunakan pada saat kegiatan, sekaligus merancang waktu pelaksanaan kegiatan dan jumlah anak didik yang akan dijadikan subjek penelitian, menyiapakan media yang akan digunakan yaitu persiapan untuk mewarnai, menggunting dan menempel (Rencana ini telah dilakukan dengan berkolaborasi dengan guru kelompok B2 sebagaimana susunan jadwal yang di tampilkan pada lampiran 1).

Kegiatan penelitian terdiri dari 2 (dua) siklus, masing-masing siklus terdiri dari 2 (dua) kali pertemuan. Setelah pelaksanaan kegiatan observasi sebelum dilaksanakannya penelitian, maka untuk lebih jelasnya, data-data temuan tentang hasil yang diperoleh peneliti bersama guru dalam kegiatan tersebut, dipaparkan seperti berikut ini :

\section{Perencanaan}

Pada siklus I dimana peneliti bersama guru kelompok B2 berkolaborasi menyusun, merancang kegiatan pembelajaran berupa Rencana Kegiatan Harian 
(RKH) sesuai dengan kurikulum yang berlaku, selanjutnya dari rancangan tersebut akan terlihat apa saja yang harus dipersiapkan dalam kegiatan $3 \mathrm{M}$ tersebut, yaitu media untuk kegiatan mewarnai, media yang digunakan pada kegiatan menggunting dan untuk menempelkan hasil karya tersebut. Selama pelaksanaan siklus I dimana dilaksanakan dalam 2 kali pertemuan yaitu pada hari : Rabu, 16 Mei 2018 dan Senin 21 Mei 2018.

\section{Pelaksanaan Tindakan}

Sebelum memulai tindakan penelitian, terlebih dahulu guru memberi pemahaman pada anak mengenai tahap-tahapan pelaksanaan tindakan, yaitu dimulai dari gambar apa yang akan diwarnai oleh anak, cara mewarnai gambar yang benar, memadukan berbagai macam macam warna hingga hasil yang diperoleh menarik, selanjutnya guru memberi petunjuk cara menggunting media yang telah diwarnai tadi lalu setelah digunting, guru memberi pemahaman pada anak bagaimana cara menempelkan bagian-bagian gambar tersebut menjadi sebuah rumah yang indah dan menarik, dalam hal ini tema yang digunakan adalah lingkunganku dengan sub tema lingkungan rumah, jadi anak-anak telah mengerti bagaimana bentuk dari rumah, penjelasan gurulah yang berperan pada anak sehingga anak dapat dengan mudah melaksanakan kegiatan $3 \mathrm{M}$ tersebut.

\section{Observasi dan Evaluasi}

Observasi dan penilaian dilaksanakan untuk memperoleh data yang akurat dan detail. Penilaian tersebut dilaksanakan mulai dari awal hingga akhir pembelajaran, mengacu pada indikator yang telah ditetapkan. Setelah evaluasi dilaksanakan maka semua perolehan nilai anak dikumpulkan dan dirangkum dalam format rangkuman penilaian untuk kegiatan tindakan siklus I. selanjutnya data dianalisis dengan perhitungan konversi nilai berdasarkan jumlah masing-masing nilai B = Baik $(\bullet), C=$ Cukup $(\sqrt{ })$, dan $K=$ Kurang $(\circ)$ yang terangkum dalam penilaian anak didik berdasarkan indikator yang ditetapkan dalam penelitian tersebut.

Berdasarkan data hasil perolehan nilai anak didik, maka dapat disimpulkan bahwa secara klasikal perolehan nilai anak didik dalam kegiatan Pengembangan Kemampuan Motorik Halus Anak Melalui Kegiatan 3 M (Mewarnai, menggunting dan menempel) mengalami peningkatan tingkat keberhasilan anak didik yaitu 
sebanyak 80\%. Untuk anak didik yang memperoleh nilai B (Baik=•) adalah

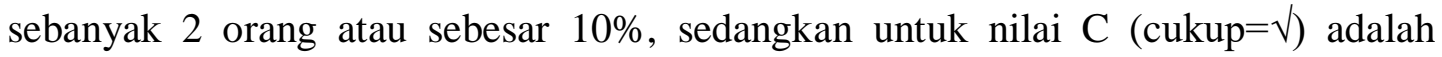
sebanyak 14 orang atau $70 \%$ sedangkan untuk yang memperoleh nikai K (Kurang=0) adalah sebanyak 4 orang atau sebesar 20\%, Pada penelitian tahap 2 tersebut masih ada anak didik yang memperoleh nilai Kurang (K) tetapi melihat kondisi yang demikian hal tersebut dipandang sebagai hal yang minim dan anak tersebut tentu dapat menyelesaikan tugas yang diberikan tetapi belum optimal dalam mengerjakannya, selain itu pula dengan perolehan nilai yang $80 \%$ tersebut dapat dikatakan bahwa rangkaian kegiatan penelitian dalam rangka mengembangkan kemampuan motorik halus anak melalui kegiatan $3 \mathrm{M}$ (mewarnai, menggunting dan menempel) dipandang telah terselesaikan dan mencapai tingkat keberhasilan dan sesuai dengan indikator kinerja dan keberhasilan yang telah ditetapkan dalam penelitian ini yaitu jika secara klasikal perolehan nilai keberhasilan anak didik mencapai $75 \%$ atau anak berada pada rentang nilai $1,50-3,00$.

Adapun selain pengamatan perolehan nilai kemampuan anak didik juga dalam penelitian ini dilakukan pengamatan pada beberapa aspek, yaitu sebagai berikut :

1. Faktor anak didik

Anak-anak sangat menyenangi kegiatan ini, dimana mereka dengan asyik mewarnai gambar rumah yang disediakan lalu menggunting dengan hati-hati agar hasil karya mereka bagus lalu menempel pola tersebut membentuk sebuah benda tiga dimensi. Seluruh anak aktif pada kegiatan yang diberikan, tetapi tentu saja masih ada yang selalu bertanya mengenai yang dilakukan, tetapi hal ini bukanlah suatu masalah besar bagi guru dimana setiap anak kita ketahui memilikimkemampuan yang berbeda-beda.

\section{Faktor Guru}

Guru telah banyak mengadakan perbaikan pada tahapan siklus 2 ini, dimulai dari pemberian materi pada anak khususnya pada kegiatan 3M (mewarnai, menggunting dan menempel), pemberian pemahaman tersebut terkesan menarik dan sangat menyenangkan sehingga anak-anak mudah mengerti mengenai apa yang akan dilaksanakan. Perencanaan yang dilaksanakan sudah dipersiapkan sebaik-baiknya dan guru senantiasa melaksanakan dengan seoptimal mungkin, sebagai bahan perbaikan dari siklus sebelumnya. Pengelolaan kelas yang 
dijalankan gurupun sudah baik, sedangkan media serta alat peraga yang digunakan dalam penelitian sebanding dengan jumlah anak didik yang melaksanakan kegiatan penelitian, sehingga anak-anak bebas untuk melaksanakan kegiatan penelitian.Yang terpenting pula adalah guru senantiasa membimbing anak-anak yang belum dapat melaksanakan kegiatan dengan baik serta selalu memberi penghargaan pada anak untuk lebih percaya diri.

\section{Refleksi}

Berdasarkan kegiatan penelitian yang dilakukan di siklus II dimana tindakan penelitian yang dilaksanakan berdasarkan perencanaan yang terangkum dalam Rencana Kegiatan Harian (RKH), instrument penilaian serta pengamatan selama berlangsungnya kegiatan pembelajaran, hasil analisis data yang diperoleh berdasarkan kemampuan anak didik maka hasil yang diperoleh secara klasikal pada anak didik kelompok B2 TK Al-Ittihad Luwuk pada tahap siklus II mencapai 80\%, maka berdasarkan ketetapan indikator kinerja yang digunakan pada penelitian ini guru kelompok B2 serta peneliti sepakat untuk menghentikan kegiatan penelitian sebab sudah mencapai target yang diinginkan dan penelitian tersebut dipandang telah terselesaikan.

\section{Pembahasan}

Kegiatan dalam rangka mengembangkan kemampuan motorik halus anak melalui kegiatan 3M (mewarnai, menggunting dan menempel) pada penelitian kali ini, berdasarkan data hasil yang diperoleh dan dideskripsikan pada halaman sebelumnya dapat diasumsikan bahwa kegiatan tersebut dilaksanakan dengan kemampuan yang maksimal oleh guru serta peneliti dimana telah di rancang, disusun serta dilaksanakan dengan seoptimal mungkin, dimulai dari tahap siklus I dan II sangat memberi manfaat bagi perkembangan kemampuan anak didik khususnya kemampuan motorik halus anak serta aspek-aspek lain seperti melatih kesabaran anak, ketelitian anak, melatih untuk bertanggung jawab dan lain sebagainya.

Pengalaman langsung bagi anak sangat penting dimana dengan belajar melalui pengalaman anak - anak akan memperoleh berbagai pengetahuan yang besar manfaatnya bagi kehidupan anak dikemudian hari. Kemampuan anak semakin berkembang sebab jika kita tunjau dari kemampuan anak di awal observasi sebelum 
dilaksanakan kegiatan penelitian mencapai 30\% selanjutnya pada tahap penelitian siklus I mencapai $65 \%$ sedangkan pada siklus II berkembang lagi dengan perolehan nilai sebesar $80 \%$.

Berdasarkan hal tersebut dapat diketahui daya pemahaman anak semakin berkembang dan kemampuan anak berkembang terutama motorik halus anak tersebut khususnya di kelompok B2 TK Al-Ittihad Luwuk.

\section{KESIMPULAN}

Adapun perolehan nilai pada kemampuan anak didik dan observasi yang dilaksanakan di kelompok B2 TK Al-Ittihad Luwuk Tahun Pelajaran 2018/2019, menyatakan bahwa dalam rangka mengembangkan kemampuan motorik halus anak melalui kegiatan $3 \mathrm{M}$ (mewarnai, menggunting dan menempel) menunjukkan bahwa kemampuan motorik halus anak didik semakin berkembang dan menjadi lebih baik dibandingkan sebelum pelaksanaan tindakan penelitian.

Pada penilaian yang dilakukan, pada penilaian / observasi awal anak didik memperoleh nilai ketuntasan secara klasikal sebesar (30\%) yaitu 6 dari 20 anak didik sebagai subyek penelitian dan secara individual pada siklus I mencapai 65\% yaitu 13 anak dari 20 anak secara keseluruhan di kelompok B2, kemudian pada tes siklus II diperoleh nilai ketuntasan secara klasikal sebesar $80 \%$, diperoleh nilai ketuntasan secara individual yaitu 16 anak dari 20 anak sebagai subyek penelitian. sehingga dapat disimpulkan bahwa melalui kegiatan $3 \mathrm{M}$ (mewarnai, menggunting dan menempel) dalam mengembangkan kemampuan motorik halus anak didik kelompok B2 TK A-Ittihad Luwuk Tahun Pelajaran 2018/2019 dapat ditingkatkan.

\section{Saran}

\section{Bagi guru}

1. Pengalaman langsung sangat berarti bagi anak, maka guru hendaknya senantiasa memberikan pembelajaran yang mengajak anak untuk langsung berbuat dengan media yang disediakan guru.

2. Dalam pelaksanaan pembelajaran, guru TK hendaknya memberikan kebebasan dan tanggung jawab pada anak untuk berbuat, sebab anak-anak sebenarnya banyak yang dapat ia ketahui hanya gurulah atau orang dewasa yang belum memberikan banyak pada anak-anak serta guru senantiasa mempertimbangkan 
materi, media dan strategi yang tepat untuk anak didik dan guru dituntut untuk selalu kreatif dan inovatif dalam mencipta alat-alat pembelajaran penunjang, inovatif.

\section{Bagi Peneliti}

Dengan adanya hasil penelitian yang membuktikan bahwa melalui pengalaman langsung khususnya pada kegiatan 3 (mewarnai, menggunting dan menempel) merupakan sarana bagi anak untuk mengembangkan kemampuan motoriknya dan berlatih untuk menjadi anak yang bertanggung jawab. Jadi diharapkan bagi peneliti selanjutnya dapat mengangkat kembali permasalahan yang sama tetapi dengan metode, teknik dan strategi yang lain serta tindakan yang berbeda agar dapat memberi masukan atau temuan-temuan baru dalam mengembangkan potensi anak didik khususnya di taman kanak-kanak secara optimal.

\section{DAFTAR PUSTAKA}

Iskandar, Beni. (2009) Pengembangan Kreativitas Melalui Gerak dan lagu. Materi Pokok Diklat Pengembangan Kreativitas Anak TK. Jakarta: Pusat Pengembangan dan Pemberdayaan Pendidik dan Tenaga Kependidikan TK dan PLS.

Mahendra. (1998). Belajar dan Pembelajaran Motorik. Bandung: Andira.

Masitoh, dkk. (2005). Pendekatan Belajar Aktif di TK. Depdiknas, Dirjen Dikti, Direktorat Pembinaan Tenaga Kependidikan dan Ketenagaan Perguruan Tinggi, Jakarta.

Soemantri. (2005) Metode Pengembangan Keterampilan Motorik Anak Usia Dini. Jakarta: Direktorat Jenderal Pendidikan Tinggi. 